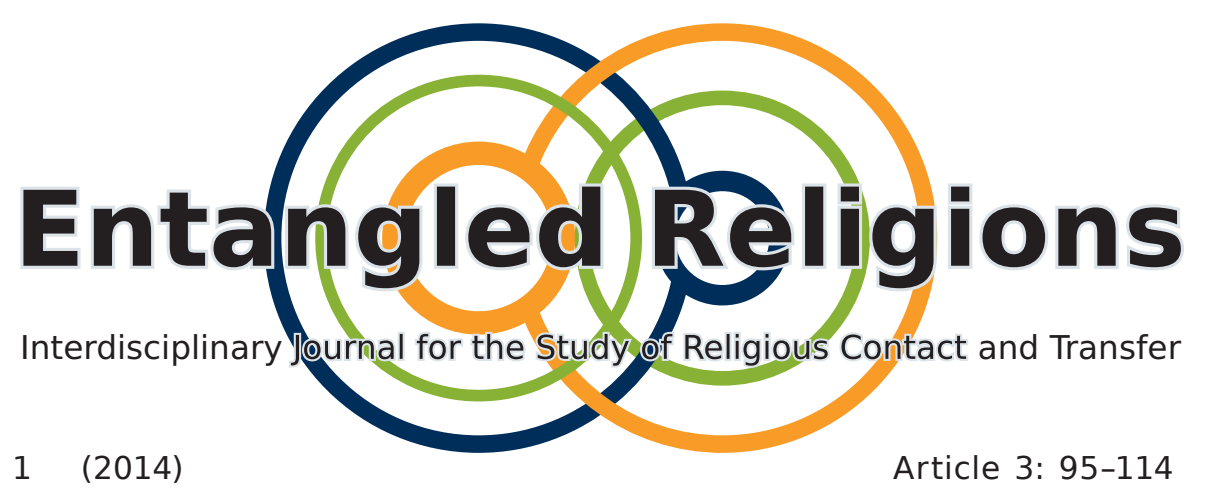

Reclaiming the Spirit through the Body: The Nascent Spirituality of Modern Postural Yoga

STUART RAY SARBACKER

School of History, Philosophy, and Religion

Oregon State University, USA

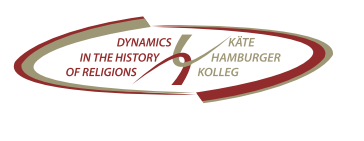




\title{
Reclaiming the Spirit through the Body: The Nascent Spirituality of Modern Postural Yoga
}

\author{
STUART RAY SARBACKER
}

Oregon State University

\begin{abstract}
In viewing physical practice as instrumental, traditions of modern postural yoga contain an implicit spirituality that echoes its historical precursors in the medieval traditions of hathayoga. The physicality of modern postural yoga tradition links the practices of premodern hațhayoga traditions with disciplines of body that are characteristic of modern cosmopolitanism, such as gymnastics and calisthenics. The principal modern yoga gurus of the twentieth century - such as B. K. S. lyengar and K. Pattabhi Jois-viewed postural yoga as distinct from purely physical disciplines on the basis that yoga has an inner dimension that other systems do not possess. Contemporary yoga practitioners have sought to make this inner dimension more transparent through appeals to traditional Hindu and Buddhist philosophy and by adopting practices that are explicitly contemplative or spiritual in nature.
\end{abstract}

KEY WORDS postural yoga, hațhayoga, cosmopolitanism, B. K. S. Iyengar, K. Pattabhi Jois, inner dimension, Hindu philosophy, Buddhist philosophy

\section{Introduction}

Traditions of modern yoga, exemplified by the cosmopolitan and globalized traditions of B. K. S. lyengar, K. Pattabhi Jois, and Bikram Choudhury, among others, are characterized by strong emphasis on the physical dimension of yoga. This preoccupation, especially with yoga āsana, or posture, has become a touchstone for the development of both sectarian and postsectarian yoga traditions across the globe. According to De Michelis (2004, 187-93), distinct branches or types of modern yoga can be distinguished. These include modern postural yoga, such as lyengar yoga, 
and modern meditative yoga, such as Transcendental Meditation (TM). However, it is clear that practitioners view the emphasis on physicality, which is found in posture-driven traditions, not as precluding mental and spiritual development but rather as encompassing those elements. De Michelis notes that lyengar himself developed multiple levels of discourse corresponding to the relative emphasis on the physical, energetic, and mental implications of yoga practice (208-47), a sort of exoteric-esoteric dynamic in his yoga that extends out of the perfection of the foundation of yoga āsana. This paper argues that such postural yoga traditions, though modern in the fullest sense, collapse spiritual development into physical development in a manner that displays important similarities to the focus on the body found in medieval hațhayoga traditions of Hinduism. It will be demonstrated that through understanding how physical and spiritual development are correlated in hațhayoga traditions, the nascent spiritual dimension of modern Hindu-derived postural yoga traditions becomes significantly more transparent. The way in which the physical emphasis in postural yoga serves both as a link to its premodern history and as the pragmatic grounds for its adoption as a modern practice also becomes apparent. Last, it will be shown that contemporary practitioners of yoga are seeking to develop a coherent philosophical framework in which to situate their experience of the physical, and especially postural, dimension of modern yoga and thereby turn over a new leaf in the history of yoga traditions.

\section{The origins of modern yoga}

An emerging body of scholarship has generated significant complexity in our understandings of the development of modern yoga traditions in 
the twentieth century. Among contemporary studies that have brought philosophical and historical methods to bear on modern traditions, the work of a handful of scholars, including Joseph Alter $(2000,2004)$, Mark Singleton (2010), and Norman Sjoman (1996), stands out. Their work has revealed that modern yoga is, in fact, thoroughly modern in that it is a product of a particular historical moment in the twentieth century in which many of the principles of modernity had reached their zenith. The foundation for modern postural yoga practice is the medieval and early modern practice of hațhayoga, or the "yoga of force," a system of yoga that utilized posture (āsana) and breath control (prāṇāyāma) as central techniques for transforming the energies of the body (or "subtle body") in such a way as to effect spiritual transformation. The emphasis on these two dimensions of yoga in modern traditions demonstrates the prominence of these two limbs (anga) of yoga in the eighteenth and nineteenth centuries, leading up to the modern period. ${ }^{1}$ However, the link to the hațhayoga traditions is only one element in the complex formulation of modern yoga. One major part of the picture, documented by Alter and others, is that the physical culture of hațhayoga served as a bridge to the physical culturalist movement and a larger callisthenic craze that swept India and the globe in the early 1900s.

Modern yoga thus is the product of the integration of a range of philosophical and physical cultures at a moment in Indian history where cosmopolitan currents were flowing at an accelerating pace and the nation itself was emerging from the colonial era. The threads that were woven together included Indian religious theories and practices of yoga, especially hațhayoga traditions; empiricism and scientific thought; European physical

1 This use of the term limb (anga) is with reference to the notion of "limbed" systems of yoga found in Indic traditions, such as the formulations of yoga referred to as șaḍangayoga ("six-limbed yoga") and așțāngayoga ("eight-limbed yoga"), in which āsana and prāṇāyāma are often members. 
culturalist thought; callisthenic fitness culture; European gymnastics and bodybuilding; Indian wrestling, gymnastics, and martial arts traditions; and Indian nationalist ideology. As Mark Singleton $(2010,208)$ writes in his work Yoga Body: The Origins of Modern Posture Practice:

The history of modern physical culture overlaps and intersects with the histories of para-religious, "unchurched" spirituality; Western esotericism; medicine, health, and hygiene; chiropractic, osteopathy, and bodywork; body centered psychotherapy; the modern revival of Hinduism; and the sociopolitical demands of the emergent modern Indian nation (to name a few). In turn, each of these histories is intimately linked to a transnational, anglophone yoga.

The transformation of modern yoga into a transnational entity, one that extends across cultural and geographical boundaries, is rooted in its origin in the cosmopolitan zeitgeist of early twentieth-century India (Strauss 2005, 87-114; Sarbacker 2008, 161-83). In particular, the combination of favoring a scientific frame over yoga metaphysic, of fusing the physical culture of hațhayoga with Indian and European disciplines, and of championing of yoga in popular media by prominent cultural icons (such as Yehudi Menuhin) served to juxtapose the exotic and the familiar in a manner that created multiple points of interface for yoga in modern society. The fact that yoga is both exotic and familiar at the same moment - both within and outside of India - has quite likely been one of its greatest appeals. In other words, the discourses and practices of modern yoga are coextensive with a modern cosmopolitan (and largely Euro-American) and globalized culture as they play on familiar themes while at the same time retaining the glimmer of something exotic or foreign. Likewise, Agehananda Bharati's so-called pizza effect - the cyclical flow of practices from one part of the world to others 
and back again-creates conditions that allow the processes through which modern yoga has arisen to be reified and further augmented by the implications (cultural and economic) of yoga as an authoritatively Indian tradition that returns to India transformed. In other words, the status of yoga, which for most 19th century Hindus was not of major significance in their everyday life, has become magnified through the attention that it has received outside of India; likewise, a globalized yoga has returned to India and has transformed native understandings and practice. With the rise of the Divyayog movement of Swami Ramdev, arguably as a culmination of this process, the sheer popular scope of the practice of modern forms of yoga in contemporary India is unprecedented in Indian history, a counterpart of the rise of yoga as an iconic global spirituality outside of India (Sarbacker 2014, 356-58).

\section{Modern postural yoga and modern meditative yoga}

In a recent work on modern yoga, De Michelis developed a scheme for understanding the branches of modern yoga that has proven quite influential. Two of the primary branches that she identifies are modern postural yoga, or MPY, and modern meditative yoga, or MMY. This differentiation reflects the focus of MPY on development of the body and the focus of MMY on the development of the mind, as well as the way in which these foci have come to characterize modern yoga traditions in an overarching manner. A key example of MPY would be the tradition of lyengar Yoga, which is characteristically focused on developing a great degree of "alignment" within yoga postures (āsana), which involves a careful awareness and study of the kinesthetic and anatomical qualities 
of such postures. Quintessential of MMY, the Transcendental Meditation system of Maharishi Mahesh Yoga is centered principally on the recitation of mantras, or verbal incantations, such as OM, while in a seated position.

The split between MPY and MMY traditions is due to a number of factors, one of the primary ones being the shift toward MPY as a bridge to modern conceptions and concerns about the body. As mentioned above, MPY as a modern form of practice appeals to a culture-neutral cosmopolitan domain while retaining its mystical and exotic air in other ways. In its focus on the body and its shift away from a metaphysical or overtly religious standpoint, it appeals to the broader assumptions and commitments of its audience, one that is concerned with fitness and health-perhaps spiritually curious, but suspicious of sectarian language and commitments. MMY traditions may pursue this course as well; the TM tradition has an extensive history of performing "scientific" studies of the health benefits of the TM meditation system, arguing that the effects of TM are measurable and practical. However, MPY traditions have wielded a stronger and more successful campaign in this regard, with the body as a sort of lingua franca in the cultural translation process. The physical disciplines-athletics, calisthenics, gymnastics, martial arts, and so forth - are analogous to yoga in clear and identifiable ways, partly because they are woven into the very fabric of modern yoga. With respect to a discipline like TM, the closest comparative analogue might be prayer, a resonance that potentially brings TM into much closer proximity to religion than to therapeutic or healing systems of the types associated with MPY. Postural forms of yoga have, and have had, a winning argument in the global dissemination of yoga, and of culture, since they conform to the expectations of their audience. They are adapted in numerous ways to strengthen ties while reducing alienation. As the postural forms of yoga have moved further away from their sectarian roots, they have deepened their penetration of global physical culture, 
especially through their adoption in various fitness mediums, extending into the private and public gymnasium as well as into the yoga studio.

On the other hand, it would be premature to dismiss postural forms of yoga for having completely discharged the spiritual side of yoga in favor of its physical element. One reason is that even in the most secularized environments, yoga still retains a glimmer of its mystique and spiritual appeal-even if it is simply the idea of "feeling great" after a yoga session. Among those outside of the Indian context, yoga is associated positively with the exotic and spiritual; within India, it is associated with the catching-on of a native tradition, with a sense of the significance of the practice as part of the Hindu tradition of renunciation. A second reason, and the one that will be examined here in more detail, is that the principal proponents and formulators of modern yoga do not see the physicality of yoga as an impediment to spiritual development but rather believe that there is an inner practice of yoga that brings spiritual depth to its performance. In fact, a large number, if not the majority, of contemporary cosmopolitan forms of postural yoga are descended from the teachings of B. K. S. Iyengar and K. Pattabhi Jois, who both articulated visions of yoga in which spiritual transformation occurs within what might be viewed as the trappings of a physical practice. This conception of inner transformation within outer transformation represented in postural traditions exists in latent form within even the most radically physical traditions of yoga. This can be related to the fact that modern yoga is descended from hațayoga traditions, in which a similar physical-spiritual dynamic exists. To the Indian understanding, physical discipline has mental and spiritual effects, regardless of the motivation for performing such discipline. It can also be connected to the idea that yoga "bridges the gap" between body and mind or spirit, or both - that there is a "science of yoga" that transcends the dualisms that characterize modernity. 


\section{B. K. S. lyengar and K. Pattabhi Jois: Bridging the gap}

What is the difference between yoga and physical exercise or calisthenics? This question addresses the crucial difference in perception of yoga as a form of exercise or as a form of spirituality or philosophy. Is there a difference, or is yoga essentially an Indian exercise system that has been co-opted in the modern era by various Hindu and non-Hindu proponents? This question has been directly answered by two of the most important figures in the formation of modern yoga, B. K. S. Iyengar and K. Pattabhi Jois. lyengar and Jois were both the disciples of Tirumalai Krishnamacharya (1888-1988). Tirumalai Krishnamacharya was a major formulator of modern yoga in the early twentieth century, who lived in Southern India, notably in the cities of Mysore and Chennai. Krishnamacharya is considered by many in the contemporary context to be the father of modern yoga, as he was instrumental in developing movement-oriented postural systems that have been extremely influential (Singleton and Fraser 2014, 83-84). Krishnamacharya's disciples, most prominently lyengar and Jois, succeeded to degrees greater than their guru: they brought yoga to an international and cosmopolitan audience. Though lyengar and Jois emphasized different parts of Krishnamacharya's teachings, adapted and augmented them in important ways, they both drew upon the physicality of his system in a compelling way. However, both lyengar and Jois continued to see yoga as something more than a system of physical discipline or exercise. In Light on Yoga, lyengar ([1977] 1994, 57) argues, "practice of āsanas without the backing of yama and niyama [ethical restraint and spiritual discipline] is mere acrobatics." More recently, in his work Light on Life, lyengar (2005a, 47) stated that yoga is characterized by a transformative encounter with pain rather than a "grin and bear it" attitude, which would be characteristic 
of callisthenic exercises. Jois $(2002,40)$, on the other hand, states in his work Yoga Mala that "the Sun Salutations [a ubiquitous practice in modern yoga] done without following the rules mentioned above [the use of linked movement, breath control, meditation, gaze, and energetic locks] are little more than exercise." In the case of lyengar, the stated focus is upon the proper ethical and contemplative perspective. For Jois, the emphasis is on the inner practice of concentration and energy control. In both cases, these observances are understood to separate true yoga from calisthenics or physical exercise.

This further suggests, as Gudrun Bühnemann (2007, 17-24) has argued, that the limbs or elements of yoga that are more clearly moral, contemplative, or spiritual are understood as being found within, or as framing the postural practice of yoga. Following in the footsteps of Krishnamacharya, both lyengar and Jois frame their practice of yoga in light of the așțāngayoga rubric of Patañjali, the so-called eight-limbed yoga. However, their mode of practice is more characteristically modern, being informed by the physical disciplines with which it is in conversation, but also drawing heavily upon the premodern hathayoga traditions for inspiration. The physical body as an object of focus is both an entry point into the practice of yoga and the place in which the spirituality of yoga is focused and expanded. It is a neutral point of reference, eminently familiar, and at the same time an opening to the spiritual dimension of yoga. It is worth noting that in Light on Yoga and Yoga Mala, lyengar and Jois present their respective visions of yoga that situate it clearly within a philosophical and religious context; however, the practice portion of each work makes little reference to the spiritual or philosophical, but rather emphasizes technical detail. The generic postural yoga and movement-oriented vinyāsa styles of yoga that descend from these traditions are further distanced from many assumptions and assertions in the works of lyengar and Jois. The often 
implicit spirituality of yoga might be said to bridge the modern religioussecular gap (Van der Veer 2009, 1097) in satisfying ways and to offer a new way of relating to the body that appeals to an idealized notion of self — what it might become - that has cross-cultural appeal (Srinivas 2010, 203). It may also point to a mode of spirituality or religiosity that is defined by action-orthopraxy-as opposed to its doctrinal or philosophical elements. This implicit identity is made explicit in shared structural forms of embodiment (Holdrege 1999, 37-39).

\section{Collapsing the spirit into the body: The analogue of hathayoga and the dawn of the "science of yoga"}

What should be noted here is that the collapsing of the spiritual into the physical, the esoteric into the exoteric, bears a strong resemblance to the methodologies of the hațhayoga traditions that are the foundation for much of modern yoga practice. Hațhayoga, the "yoga of force," is a medieval system that utilizes physical actions-most notably āsana (posture), and prānāyāma (breath control) - for the purpose of effecting spiritual liberation and the attainment of occult powers. Hathayoga is a method for obtaining spiritual perfection (siddhi), which can be understood in terms of both liberation and magical power, as one of the most wellknown hațhayoga texts, the Hațhayogapradipikā (also known as the Hațhapradīpikā), attests (HYP I.11). There, hațhayoga is described as being performed for the purpose of rājayoga, the "royal yoga" (HYP I.1, II.76). Rājayoga is a term for the practice of deep meditation (samādhi) outlined in the yoga system propounded in the Yogasūtra, the formative text on yoga from the early centuries of the Common Era. In the fourth chapter of the 
Hațhayogapradīpikā, rājayoga is equated with a range of terms indicating meditative mastery and spiritual perfection-terms including samādhi, unmanī, manonmanī, amaratva, laya, tattva, śūnyāśūnya, paramapada, amanaska, advaita, nirālamba, nirañjana, jīvanmukti, sahaja, and turya (HYP IV.3-4). It is obtained principally through the arresting of vital air (prāṇa) through a particular type of breath control (prāṇāyāma) referred to as (kevala) kumbhaka, in which both inhalation and exhalation are arrested (HYP II.71-78, IV.6). The mastery of arresting prāṇa is augmented through obtaining proper posture (āsana), through breath control (prānāyāma) and control of the flow of energy in the body through "bindings" (bandha) and "seals" (mudrā). The point to be emphasized here is that hațhayoga is construed as being a system of physical (and, by extension, energetic) practice that facilitates the development of deep contemplative states in which mind meets spirit and a state of liberation and power is conferred. Rājayoga is seen as extending naturally (if not being forcibly effected) from the proper control of the body and its energetic structure. The meditative process of rājayoga is validated but simultaneously subsumed under the rubric of hațhayoga. This follows a larger emphasis within the Hațhayogapradīpikā in which various yogic methodologies, including those of earlier systems of layayoga and mantrayoga, are subsumed within the practice of hațayoga (Mallinson 2011, 773), perhaps anticipating the synthetic nature of modern yoga in important ways.

In this collapsing of the spiritual or mental into the physical, the idea of a process whereby the transformation of the body and breath is seen by a practitioner as effecting a deeper spiritual transformation, parallels the persistence of an inner spirituality in modern postural yoga traditions. One main difference, however, is the manner in which the inner, energetic body is understood and addressed in the context of practice. This is where hathayoga concepts of the energetic body give way to modern yoga 
ideas such as that of "alignment." These ideas contain notions of perfect yoga posture and its transformative potential as tangible structural and physical processes. Likewise, the notion of the transformation of spirit through the opening of the energetic body, or of emotional life through the development of deep flexibility and joint mobility (such as through elaborate back-bending techniques found in traditions such as Jois's) offers an analogue to medieval Indian conceptions of the subtle body with its channels (nāọi) and wheels (cakra), while still approximating and referencing modern anatomical and physiological conceptions of the body in a direct way. It is paralleled by the manner in which, as Alter $(2004,73-$ 108) demonstrates, the prominent yoga modernist Swami Kuvalayananda sought to analyze a spectrum of yogic practices within the framework of a modern medical paradigm in order to demonstrate the effects of these practices in physiological terms.

In the lyengar and Jois traditions, medieval conceptions of the subtle energetic body are not wholly abandoned - rather, they serve as a framing narrative for understanding how energy or the spirit can be manifested in the body in subtle and concrete ways. The purification of the human body through the destruction of disease is a first step toward the realization of an innermost self that is the "nature of supreme peace and eternal bliss" (Jois 2002, 3-31), or, alternatively, "the true union of our will with the will of God" (lyengar [1977] 1994, 19). To turn this argument around, it might also be asked to what degree that the formulation of hațhayoga during yoga's medieval era represented a coming to terms with what were then contemporary shifts in body culture due to the dissemination of previously foreign conceptions of the body, from China or Central Asia for example, and through the development of indigenous tantric conceptions of the body that drew on non-Brāhmaṇical (i.e., non-priestly) sources. Likewise, the so-called classical yoga tradition of Patañjali's Yogasūtra is quite clearly an 
attempt to synthesize and organize both Brāhmaṇical (priestly) and nonBrāhmaṇical (i. e., Buddhist and Jaina) conceptions of yoga and asceticism in a coherent and orthodoxy-friendly way. Larger conceptions regarding the constitution of the mind and body, along with pervasive bodily disciplines and practices, provide a framework in which practices of yoga are understood in all of these contexts. Modern yoga traditions in this regard are analogous to, and as authentic as, their historical counterparts in their assimilation of the ideas and practices that frame embodiment in the modern context. They were founded in the tensions of a time of great upheaval in India, and thus they are both products of and productive of global processes. As Alter $(2004,106)$ comments with respect to Kuvalayananda's research project on the physiology of yoga,

The programmatic features of this research, as its creative confusion reveals the parameters of a distinctive ontology, has more to do with an alternative global modernity than with the manifest tension between colonialism and nationalism, East and West, as these tensions are localized in India. The global reach of science makes this possible, but the cosmic scope of Yoga's ontology prevents Yoga from being subsumed by the epistemology to which it is subject.

The appeal of this 'physicalism' of modern yoga traditions, in part a product of such exercises in cross-cultural production, is exemplified in the often repeated phrase "science of yoga," which encapsulates the modern figuration of yoga as appealing to a universal, transnational, and transcultural truth. In this spirit, the multifaceted role of the modern yoga teacher is summarized thus by B. K. S. Iyengar (2005b, 9): “When I practice, I am a philosopher. When I teach, I am a scientist. When I demonstrate, I am an artist." With respect to yoga as science, Jois $(2002,83)$, in discussing 
the need for control of the senses as a means of naturally effecting birth control and leading to greater social harmony, reflects:

Thus, those that want to lead long, happy lives free from illness, and want to bring forth offspring who are healthy and intellectual, must take to the philosophy of yoga and its practices. This the science of yoga declares like the sounding of a drum. And this I say again to the youth of today, so strongly do I feel about the matter.

But ultimately, for Jois $(2002,111)$, the goal of the "science of yoga" is to embody the practice, become spiritually transformed and thus capable of compassionately helping the world:

In the modern world, people have many kinds of fears and inaccurate notions about the science of yoga. In order to allay such fears and correct such notions, the path of yoga should first be practiced in accordance with the scriptures, its fruits experienced, and then be passed on to others. As many great people in the world are knowledgeable about the science of yoga, they should foster able disciples, direct them on the proper path, and then send them forth for the benefit of the universe.

\section{Conclusion: Reclaiming the spirit through the body}

Contemporary postural yoga traditions, many of which are extensions and adaptations of the modern traditions of lyengar and Jois, continue to pursue the spiritual and philosophical dimension of yoga by finding ways to integrate contemplation within the framework of postural practice. Traditions with 
deep connection to lineage, like those of lyengar and Jois, allow members to swim upstream and pursue the philosophical and spiritual dimensions of yoga by delving deeper into the background of their teachers and their teachers' traditions. In the case of lyengar, a deep legacy of physicalism in practice is complemented by a wide-ranging collection of written works on Indian philosophy and yoga spirituality that has, for the most part, sated his disciples who have pursued such an interest. This is in addition to a clearly articulated and understood principle found in lyengar yoga: that postural practice itself is not simply a physical exercise but offers true opportunities for self-realization. The Krishnamacharya lineage has more generally drawn students towards the așțāngayoga system and the literature of yoga, especially the Yogasūtra, due to its having being championed by the guru and his successors. One example of the extrapolation of yoga philosophy in this vein is the recent work by yoga teacher and scholar Michael Stone (2008), entitled The Inner Tradition of Yoga: A Guide to Yoga Philosophy for the Contemporary Practitioner, in which a disciple of Pattabhi Jois works to articulate a larger philosophical framework for understanding the contemporary practice of yoga, integrating both Pātañjala yoga and Buddhist philosophy. The goal of such work is to reconstruct the conceptual framework of yoga, focusing on the notion of the integration of the philosophical and spiritual into the physical practice of yoga. In this respect, work like Stone's represents a reflection upon the modern collapsing of contemplation into body-focused practice, and a contemporary concern for the reclamation or reconstruction of a philosophical context for the practice of modern yoga. Another contemporary approach to bringing a philosophical and contemplative perspective to the physical dimension of yoga is the integration of Buddhist techniques of mindfulness meditation, especially insight meditation (vipassanā), into āsana practice. A notable example of this approach is Cyndi Lee's (2004) work entitled Yoga Body, 
Buddha Mind, in which a prominent American yoga teacher applies her experience in mindfulness meditation to yoga practice, aiming to fill a gap in physical practice by offering a contemplative angle on the experience of posture. In the case of Lee, it might be argued that the distance of her physical training from its rootedness in Indian philosophy has led her to bridge to another tradition entirely, arguably drawing on a Buddhist practice that might be characterized as a MMY, or modern meditative yoga. The dichotomy of MPY and MMY thus gives way, or is transcended, in the quest for a holistic and complete approach to yoga. As a last example: In his Original Yoga (2012), Richard Rosen (a long-term lyengar practitioner), looks to medieval hațhayoga texts to tap into the roots of modern yoga traditions and to clarify the connections and disconnections between premodern and modern forms of yoga.

Modern yoga forms and their contemporary descendants exist in the tension between athletic and therapeutic physical discipline, on the one hand, and contemplative spiritual practice, on the other. In the first case, a philosophical framework already exists for understanding the purpose and effects of practice, and although this framework is for the most part unarticulated, it appeals to the language of science, healing, and self-help to contribute to its relevance for a contemporary audience. However, to the degree that modern postural yoga is understood as a contemplative or spiritual exercise, appeals to tradition and reconstructive philosophical work become necessary to make such an understanding coherent, tangible, and explicit. As the postural dimension of yoga becomes more firmly established, institutionalized, and normalized as part of a globalized contemporary culture, it is not surprising that there is greater interest in exploring the philosophical and spiritual content of these traditions in more self-conscious and deliberate ways by its committed, and often lifelong, practitioners. Through their pursuit of such a coherent framework, they are 
active participants in turning over a new leaf in yoga's long history as an Indian and global phenomenon.

\section{Reference List}

Alter, Joseph S. 2000. Gandhi's Body: Sex, Diet, and the Politics of Nationalism. Philadelphia: University of Pennsylvania Press.

Alter, Joseph S. 2004. Yoga in Modern India: The Body Between Science and Philosophy. Princeton, NJ: Princeton University Press.

Bühnemann, Gudrun. 2007. Eighty-Four Āsanas in Yoga: A Survey of Traditions. Delhi: D. K. Printworld.

De Michelis, Elizabeth. 2004. A History of Modern Yoga: Patañjali and Western Esoterism. London: Continuum.

Holdrege, Barbara. 1999. "What Have Brahmins to Do with Rabbis? Embodied Communities and Paradigms of Religious Tradition." Shofar: An Interdisciplinary Journal of Jewish Studies 17 (3): 2350.

lyengar, B. K. S. (1977) 1994. Light on Yoga: Yoga Dipika. Reprint, New York: Schocken Books.

lyengar, B. K. S. 2005a. Light on Life: The Yoga Journey to Wholeness, Inner Peace, and Ultimate Freedom. Emmaus, PA: Rodale.

lyengar, B. K. S. 2005b. Yoga: the Path to Holistic Health. London: Dorling Kindersley. 
Jois, K. Pattabhi. 2002. Yoga Mala. New York: North Point Press.

Lee, Cyndi. 2004. Yoga Body, Buddha Mind. New York: Riverhead Books.

Mallinson, James. 2011. "Hațha Yoga." In Brill Encyclopedia of Hinduism. Vol. 3, edited by Knut A. Jacobsen, 770-81. Leiden: Brill.

Rosen, Richard. 2012. Original Yoga: Rediscovering Traditional Practices of Hatha Yoga. Boston: Shambhala.

Sarbacker, Stuart. 2008. "The Numinous and Cessative in Modern Yoga." In Yoga in the Modern World: Contemporary Perspectives, edited by Jean Byrne and Mark Singleton, 161-83. New York: Routledge.

Sarbacker, Stuart. 2014. "Swami Ramdev: Modern Yoga Revolutionary." In Gurus of Modern Yoga, edited by Ellen Goldberg and Mark Singleton, 351-371. New York: Oxford University Press.

Singleton, Mark. 2010. Yoga Body: The Origins of Modern Posture Practice. New York: Oxford University Press.

Singleton, Mark, and Tara Fraser. 2014. “T. Krishnamacharya, Father of Modern Yoga." In Gurus of Modern Yoga, edited by Ellen Goldberg and Mark Singleton, 83-106. New York: Oxford University Press.

Sjoman, N. E. 1996. The Yoga Tradition of the Mysore Palace. Delhi: Abhinav.

Srinivas, Tulasi. 2010. Winged Faith: Rethinking Globalization and Religious Pluralism through the Sathya Sai Movement. New York: Columbia University Press.

Stone, Michael. 2008. The Inner Tradition of Yoga: A Guide to Yoga Philosophy for the Contemporary Practitioner. Boston: Shambhala. 
Strauss, Sarah. 2005. Positioning Yoga: Balancing Acts Across Cultures. Oxford, NY: Berg.

Swātmārāma, Swami. (1893) 1972. Hațhayogapradīpikā with the Jyotsnā of Brahmānanda and English Translation. Madras: Adyar Library and Research Center.

Van der Veer, Peter. 2009. "Spirituality in Modern Society." Social Research 76 (4): 1097-1120. 